\title{
Synthesis, Spectroscopic Characterization, Crystal Structures and Antibacterial Activity of Vanadium(V) Complexes of Fluoro- and Chloro-Substituted Benzohydrazone Ligands
}

\author{
En-Cheng Liu, ${ }^{1}$ Wei $\mathrm{Li}^{1,{ }^{*}}$ and Xiao-Shan Cheng ${ }^{2}$ \\ ${ }^{1}$ Department of Radiology, The Second Hospital of Dalian Medical University, Dalian 116023, P.R. China \\ ${ }^{2}$ Department of Chemistry and Chemical Engineering, Liaoning Normal University, Dalian 116029, P. R. China \\ *Corresponding author: E-mail: liwei_dlmu@126.com,youzhonglu@126.com
}

Received: 04-25-2019

\begin{abstract}
A new vanadium $(\mathrm{V})$ complex, $[\mathrm{VOL}(\mathrm{OMe})(\mathrm{MeOH})] \cdot \mathrm{MeOH}(\mathbf{1} \cdot \mathrm{MeOH})$, was prepared by the reaction of $\mathrm{VO}(\mathrm{acac})_{2}$ with 2-chloro- $N$ '-(5-fluoro-2-hydroxybenzylidene)benzohydrazide $\left(\mathrm{H}_{2} \mathrm{~L}\right)$ in methanol. By addition of salicylhydroxamic acid (HSHA) to the methanolic solution of $\mathbf{1}$, a new salicylhydroxamate-coordinated vanadium $(\mathrm{V})$ complex, $[\mathrm{VOL}(\mathrm{SHA})] \cdot \mathrm{H}_{2} \mathrm{O}\left(\mathbf{2} \cdot \mathrm{H}_{2} \mathrm{O}\right)$, was obtained. Both complexes were characterized by elemental analysis, infrared spectroscopy, thermal analysis and single crystal X-ray diffraction. Complex $\mathbf{1}$ crystallizes with methanol molecule as a solvate, and complex 2 as a monohydrate. The $\mathrm{V}$ atoms in the complexes are in octahedral coordination. In the crystal structure of $\mathbf{1} \cdot \mathrm{MeOH}$, the vanadium complexes are linked by methanol solvate molecules through intermolecular $\mathrm{O}-\mathrm{H} \cdots \mathrm{N}$ and $\mathrm{O}-\mathrm{H} \cdot \cdots \mathrm{O}$ hydrogen bonds to form chains along the $c$ axis. In the crystal structure of $2 \cdot \mathrm{H}_{2} \mathrm{O}$, the vanadium complexes are linked by water molecules through intermolecular $\mathrm{O}-\mathrm{H} \cdots \mathrm{O}$ hydrogen bonds, to form $1 \mathrm{D}$ chains along the $a$ axis. The chains are further linked through intermolecular $\mathrm{O}-\mathrm{H} \cdots \mathrm{N}$ and $\mathrm{O}-\mathrm{H} \cdots \mathrm{O}$ hydrogen bonds in the $c$ direction to form 2D layers. The antimicrobial activities of the complexes against K. pneumoniae, S. aureus, P. aeroginosa, E. coli, and B. subtilis were investigated.
\end{abstract}

Keywords: Hydrazone ligand; Salicylhdroxamate ligand; Vanadium complex; Crystal structure; Antibacterial activity.

\section{Introduction}

In recent years, vanadium complexes have been reported to have interesting biological activities such as normalizing the high blood glucose levels and acting as models of haloperoxidases. ${ }^{1}$ Hydrazone compounds derived from the condensation reaction of aldehydes with various hydrazides are much attractive for their structures, coordinate ability to metal atoms and extensive biological applications. ${ }^{2}$ Recently, our research group has reported a few vanadium complexes with hydrazone ligands and their biological activities. ${ }^{3}$ In general, $\mathrm{V}$ atom is readily adopt octahedral coordination. Hydrazone ligands can coordinate to the $\mathrm{V}$ atoms through three donor atoms. The remaining three positions of the octahedral coordination are usually occupied by one oxo oxygen and two solvent molecules, one with deprotonated and the other one neutral. ${ }^{3 a, 4}$ The two solvent ligands are not coordinate so strong to the $\mathrm{V}$ atom that they are readily substituted by bidentate ligands, such as benzohydroxamate, ${ }^{5}$ propane1,3-diol-2-olate or propan-1-ol-3-olate, ${ }^{6} 2$-hydroxyethanolate, ${ }^{7}$ etc. Salicylhydroxamic acid is a bidentate ligand, but very few examples of vanadium $(\mathrm{V})$ complexes with this ligand have been reported. Fluoro- and chloro-substituted compounds are reported to have effective antibacte-<smiles>O=C(N/N=C/c1cc(F)ccc1O)c1ccccc1Cl</smiles>

Scheme 1. $\mathrm{H}_{2} \mathrm{~L}$ 
rial activities. ${ }^{8}$ In the present paper, a new methanol and methoxy-coordinated vanadium $(\mathrm{V})$ complex, $[\mathrm{VOL}(\mathrm{OMe})(\mathrm{MeOH})] \cdot \mathrm{MeOH}(\mathbf{1})$ and a salicylhydroxamate (SHA) coordinated vanadium $(\mathrm{V})$ complex, [VOL(SHA)] $\mathrm{H}_{2} \mathrm{O}$ (2), where $\mathrm{H}_{2} \mathrm{~L}=2$-chloro- $N^{\prime}$-(5fluoro-2-hydroxybenzylidene)benzohydrazide (Scheme 1), are presented and studied on their antibacterial activities.

\section{Experimental}

\section{1. Materials and Measurements}

Commercially available 5-fluorosalicylaldehyde, 2-chlorobenzohydrazide and salicylhyroxamic acid were purchased from Sigma-Aldrich and used without further purification. Other solvents and reagents were made in China and used as received. C, $\mathrm{H}$ and $\mathrm{N}$ elemental analyses were performed with a Perkin-Elmer elemental analyser. Infrared spectra were recorded on a Nicolet AVATAR 360 spectrometer as $\mathrm{KBr}$ pellets in the $4000-400$ $\mathrm{cm}^{-1}$ region. Thermal stability analysis was performed on a Perkin-Elmer Diamond TG-DTA thermal analyses system. NMR spectra were recorded on a Bruker $500 \mathrm{MHz}$ instrument.

\section{2. Synthesis of $\mathrm{H}_{2} \mathrm{~L}$}

5-Fluorosalicylaldehyde $(1.0 \mathrm{mmol}, 0.14 \mathrm{~g})$ and 2-chlorobenzohydrazide $(1.0 \mathrm{mmol}, 0.17 \mathrm{~g})$ were dissolved in methanol $(30 \mathrm{~mL})$ with stirring. The mixture was stirred for about $30 \mathrm{~min}$ at room temperature to give a clear solution. The solvent was evaporated to give colorless crystalline products. Yield, 96\%. Analysis: Found: C 57.6\%, H $3.5 \%, \mathrm{~N}$ 9.5\%. Calculated for $\mathrm{C}_{14} \mathrm{H}_{10} \mathrm{ClFN}_{2} \mathrm{O}_{2}$ : C $57.4 \%, \mathrm{H}$ $3.4 \%, \mathrm{~N} 9.6 \%$. IR data $\left(\mathrm{KBr}, \mathrm{cm}^{-1}\right): v 3372(\mathrm{w}, \mathrm{OH}), 3232$ (w, NH), 1651 (s, C=O), 1619 (s, C=N). UV-Vis $(\mathrm{MeOH}$, $\mathrm{nm}): \lambda 225,289,305,330,405 .{ }^{1} \mathrm{H}$ NMR $\left(d^{6}\right.$-DMSO, ppm) $\delta 12.16(\mathrm{~s}, 1 \mathrm{H}, \mathrm{OH}), 10.77(\mathrm{~s}, 1 \mathrm{H}, \mathrm{NH}), 8.49(\mathrm{~s}, 1 \mathrm{H}, \mathrm{CH}=\mathrm{N})$, 7.61-7.42 (m, 5H, ArH), 7.17 (d, 1H, ArH), 7.03 (d, 1H, ArH). ${ }^{13} \mathrm{C}$ NMR $\left(d^{6}\right.$-DMSO, ppm) $\delta 162.85,156.78,154.91$, $146.62,135.23,132.08,131.24,130.02,128.99,127.60$, $120.31,120.25,118.82,114.13$.

\section{3. Synthesis of $[\mathrm{VOL}(\mathrm{OMe})(\mathrm{MeOH})] \cdot \mathrm{MeOH}$}

\section{(1)}

A methanolic solution $(10 \mathrm{~mL})$ of $\left[\mathrm{VO}(\mathrm{acac})_{2}\right](0.1$ mmol, $26.5 \mathrm{mg}$ ) was added to a methanolic solution (10 $\mathrm{mL})$ of $\mathrm{H}_{2} \mathrm{~L}(0.1 \mathrm{mmol}, 29.2 \mathrm{mg})$ with stirring. The mixture was stirred for $30 \mathrm{~min}$ at room temperature to give a brown solution. The resulting solution was allowed to stand in air for a few days. Brown block-shaped crystals suitable for $\mathrm{X}$-ray single crystal diffraction were formed at the bottom of the vessel. The isolated products were washed three times with cold ethanol, and dried in air. Yield, 72\%. Anal- ysis: Found: C $44.9 \%, \mathrm{H} 4.4 \%, \mathrm{~N} 6.2 \%$. Calculated for $\mathrm{C}_{17} \mathrm{H}_{19} \mathrm{ClFN}_{2} \mathrm{O}_{6} \mathrm{~V}: \mathrm{C} 45.1 \%, \mathrm{H} 4.2 \%, \mathrm{~N} 6.2 \%$. IR data $(\mathrm{KBr}$, $\left.\mathrm{cm}^{-1}\right): v 3437(\mathrm{~m}, \mathrm{OH}), 1607(\mathrm{~s}, \mathrm{C}=\mathrm{N}), 981(\mathrm{~V}=\mathrm{O})$. UV-Vis $(\mathrm{MeOH}, \mathrm{nm}): \lambda 270,325,413 .{ }^{1} \mathrm{H}$ NMR $\left(d^{6}\right.$-DMSO, ppm) $\delta 8.88(\mathrm{~s}, 1 \mathrm{H}, \mathrm{CH}=\mathrm{N}), 7.83(\mathrm{~d}, 1 \mathrm{H}, \operatorname{ArH}), 7.61-7.20(\mathrm{~m}$, $5 \mathrm{H}, \mathrm{ArH}), 6.94(\mathrm{~d}, 1 \mathrm{H}, \mathrm{ArH}), 5.26\left(\mathrm{~s}, 3 \mathrm{H}, \mathrm{CH}_{3}\right), 3.94(\mathrm{~s}$, $\left.3 \mathrm{H}, \mathrm{CH}_{3}\right) .{ }^{13} \mathrm{C}$ NMR $\left(d^{6}\right.$-DMSO, ppm) $\delta 171.50,160.25$, $156.55,154.68,132.52,132.25,131.72,131.35,131.12$, $127.60,120.73,118.19,117.97,117.78,74.54,49.07 .{ }^{51} \mathrm{~V}$ NMR ( $d^{6}$-DMSO, ppm) $\delta-555$.

\section{4. Synthesis of [ $\mathrm{VOL}(\mathrm{SHA})] \cdot \mathrm{H}_{2} \mathrm{O}$ (2)}

A methanolic solution $(10 \mathrm{~mL})$ of salicylhydroxamic acid $(0.1 \mathrm{mmol}, 15.3 \mathrm{mg})$ was added to a methanolic solution $(10 \mathrm{~mL})$ of $1(0.1 \mathrm{mmol}, 45.3 \mathrm{mg})$ with stirring. The mixture was stirred for $30 \mathrm{~min}$ at room temperature to give a deep brown solution. The resulting solution was allowed to stand in air for a few days. Brown block-shaped crystals suitable for X-ray single crystal diffraction were formed at the bottom of the vessel. The isolated products were washed three times with cold ethanol, and dried in air. Yield, 51\%. Analysis: Found: C 47.7\%, H 3.0\%, N 7.8\%. Calculated for $\mathrm{C}_{21} \mathrm{H}_{16} \mathrm{ClFN}_{3} \mathrm{O}_{7} \mathrm{~V}$ : C $47.8 \%, \mathrm{H} 3.1 \%, \mathrm{~N}$ 8.0\%. IR data $\left(\mathrm{KBr}, \mathrm{cm}^{-1}\right): v 3454(\mathrm{~m}, \mathrm{OH}), 3278(\mathrm{w}, \mathrm{NH})$, $1607(\mathrm{~s}, \mathrm{C}=\mathrm{N}), 979(\mathrm{~V}=\mathrm{O})$. UV-Vis $(\mathrm{MeOH}, \mathrm{nm}): \lambda 266$, $327,408 .{ }^{1} \mathrm{H}$ NMR $\left(d^{6}\right.$-DMSO, ppm) $\delta 12.16(\mathrm{~s}, 1 \mathrm{H}, \mathrm{OH})$, $12.10(\mathrm{~s}, 1 \mathrm{H}, \mathrm{NH}), 9.13(\mathrm{~s}, 1 \mathrm{H}, \mathrm{CH}=\mathrm{N}), 7.71-7.57(\mathrm{~m}, 4 \mathrm{H}$, ArH), 7.48-7.38 (m, 3H, ArH), 7.01-6.87 (m, 4H, ArH). ${ }^{13} \mathrm{C}$ NMR $\left(d^{6}\right.$-DMSO, ppm) $\delta 163.70,160.89,157.36$, $156.50,155.75,151.79,134.93,132.62,131.20,130.89$, $130.80,129.88,128.99,127.56,122.89,119.97,119.72$, $118.82,118.15,117.93,115.35 .{ }^{51} \mathrm{~V}$ NMR $\left(d^{6}-\mathrm{DMSO}, \mathrm{ppm}\right)$ $\delta-553$.

\section{5. X-ray Crystallography}

Diffraction intensities for the complexes were collected at 298(2) K using a Bruker D8 VENTURE PHOTON diffractometer with MoKa radiation $(l=0.71073 \AA)$. The collected data were reduced using the SAINT program, ${ }^{9}$ and multi-scan absorption corrections were performed using the SADABS program. ${ }^{10}$ The structures were solved by direct method, and refined against $F^{2}$ by full-matrix least-squares method using the SHELXTL. ${ }^{11}$ All of the non-hydrogen atoms were refined anisotropically. The coordinated methanol hydrogen atom in $\mathbf{1} \cdot \mathrm{MeOH}$ and the amino hydrogen atom in $\mathbf{2} \cdot \mathrm{H}_{2} \mathrm{O}$ were located from difference Fourier maps and refined isotropically, with $\mathrm{O}-\mathrm{H}$ and $\mathrm{N}-\mathrm{H}$ distances restrained to 0.85(1) $\AA$ and 0.90(1) $\AA$, respectively. All other hydrogen atoms were placed in idealized positions and constrained to ride on their parent atoms. The crystallographic data for the complexes are summarized in Table 1. Selected bond lengths and angles are given in Table 2. Hydrogen bonding information is listed in Table 3. 
Table 1. Crystallographic data and refinement parameters for the complexes

\begin{tabular}{|c|c|c|}
\hline & $\mathbf{1} \cdot \mathrm{MeOH}$ & $2 \cdot \mathrm{H}_{2} \mathrm{O}$ \\
\hline Chemical formula & $\mathrm{C}_{17} \mathrm{H}_{19} \mathrm{ClN}_{2} \mathrm{O}_{6} \mathrm{~V}$ & $\mathrm{C}_{21} \mathrm{H}_{16} \mathrm{ClF}-$ \\
\hline \multicolumn{3}{|l|}{$\mathrm{N}_{3} \mathrm{O}_{7} \mathrm{~V}$} \\
\hline$M r$ & 452.7 & 527.8 \\
\hline Crystal color, habit & Brown, block & Brown, block \\
\hline Crystal system & Monoclinic & Monoclinic \\
\hline Space group & $C c$ & $P 2_{1} / c$ \\
\hline \multicolumn{3}{|l|}{ Unit cell parameters } \\
\hline$a(\AA)$ & $17.938(1)$ & $7.577(2)$ \\
\hline$b(\AA)$ & $12.072(1)$ & $23.119(3)$ \\
\hline$c(\AA)$ & $10.250(1)$ & $12.393(2)$ \\
\hline$\beta\left({ }^{\circ}\right)$ & $98.617(2)$ & $97.507(2)$ \\
\hline $\mathrm{V}\left(\AA^{3}\right)$ & 2194.5(3) & $2152.4(6)$ \\
\hline $\mathrm{Z}$ & 4 & 4 \\
\hline$D_{\text {calc }}\left(\mathrm{g} \mathrm{cm}^{-3}\right)$ & 1.370 & 1.629 \\
\hline Temperature $(\mathrm{K})$ & $298(2)$ & $298(2)$ \\
\hline$\mu\left(\mathrm{mm}^{-1}\right)$ & 0.614 & 0.644 \\
\hline$F(000)$ & 928 & 1072 \\
\hline Number of unique data & 3579 & 3800 \\
\hline $\begin{array}{l}\text { Number of observed data } \\
\quad[\mathrm{I}>2 \sigma(\mathrm{I})]\end{array}$ & 2756 & 2667 \\
\hline Number of parameters & 259 & 317 \\
\hline Number of restraints & 3 & 4 \\
\hline$R_{1}, w R_{2}[I>2 \sigma(I)]$ & $0.0656,0.1666$ & $0.0410,0.0808$ \\
\hline$R_{1}, w R_{2}$ (all data) & $0.0890,0.1833$ & $0.0738,0.0926$ \\
\hline Goodness of fit on $F^{2}$ & 1.046 & 1.011 \\
\hline
\end{tabular}

Table 2. Selected bond distances $(\AA)$ and angles $\left(^{\circ}\right)$ for the complexes

\begin{tabular}{|c|c|c|c|}
\hline \multicolumn{4}{|c|}{1} \\
\hline $\mathrm{V}(1)-\mathrm{O}(1)$ & $1.849(4)$ & $\mathrm{V}(1)-\mathrm{O}(2)$ & $1.975(4)$ \\
\hline $\mathrm{V}(1)-\mathrm{O}(3)$ & $1.580(5)$ & $\mathrm{V}(1)-\mathrm{O}(4)$ & $1.747(4)$ \\
\hline $\mathrm{V}(1)-\mathrm{N}(1)$ & $2.129(5)$ & $\mathrm{V}(1)-\mathrm{O}(5)$ & $2.289(5)$ \\
\hline $\mathrm{O}(3)-\mathrm{V}(1)-\mathrm{O}(4)$ & $102.1(2)$ & $\mathrm{O}(3)-\mathrm{V}(1)-\mathrm{O}(1)$ & $100.2(2)$ \\
\hline $\mathrm{O}(4)-\mathrm{V}(1)-\mathrm{O}(1)$ & $103.2(2)$ & $\mathrm{O}(3)-\mathrm{V}(1)-\mathrm{O}(2)$ & $96.6(2)$ \\
\hline $\mathrm{O}(4)-\mathrm{V}(1)-\mathrm{O}(2)$ & $93.5(2)$ & $\mathrm{O}(2)-\mathrm{V}(1)-\mathrm{O}(1)$ & $153.1(2)$ \\
\hline $\mathrm{O}(3)-\mathrm{V}(1)-\mathrm{N}(1)$ & $94.8(2)$ & $\mathrm{O}(4)-\mathrm{V}(1)-\mathrm{N}(1)$ & $160.2(2)$ \\
\hline $\mathrm{O}(1)-\mathrm{V}(1)-\mathrm{N}(1)$ & $83.6(2)$ & $\mathrm{O}(2)-\mathrm{V}(1)-\mathrm{N}(1)$ & $74.2(2)$ \\
\hline $\mathrm{O}(3)-\mathrm{V}(1)-\mathrm{O}(5)$ & $175.5(2)$ & $\mathrm{O}(4)-\mathrm{V}(1)-\mathrm{O}(5)$ & $82.1(2)$ \\
\hline $\mathrm{O}(1)-\mathrm{V}(1)-\mathrm{O}(5)$ & $80.3(2)$ & $\mathrm{O}(2)-\mathrm{V}(1)-\mathrm{O}(5)$ & $81.4(2)$ \\
\hline $\mathrm{N}(1)-\mathrm{V}(1)-\mathrm{O}(5)$ & $80.8(2)$ & & \\
\hline \multicolumn{4}{|c|}{2} \\
\hline $\mathrm{V}(1)-\mathrm{O}(1)$ & $1.863(2)$ & $\mathrm{V}(1)-\mathrm{O}(2)$ & $1.942(2)$ \\
\hline $\mathrm{V}(1)-\mathrm{O}(3)$ & $2.185(2)$ & $\mathrm{V}(1)-\mathrm{O}(4)$ & $1.872(2)$ \\
\hline $\mathrm{V}(1)-\mathrm{N}(1)$ & $2.081(2)$ & $\mathrm{V}(1)-\mathrm{O}(6)$ & $1.577(2)$ \\
\hline $\mathrm{O}(6)-\mathrm{V}(1)-\mathrm{O}(1)$ & $99.2(1)$ & $\mathrm{O}(6)-\mathrm{V}(1)-\mathrm{O}(4)$ & $95.6(1)$ \\
\hline $\mathrm{O}(4)-\mathrm{V}(1)-\mathrm{O}(1)$ & $107.8(1)$ & $\mathrm{O}(6)-\mathrm{V}(1)-\mathrm{O}(2)$ & $102.0(1)$ \\
\hline $\mathrm{O}(1)-\mathrm{V}(1)-\mathrm{O}(2)$ & $150.6(1)$ & $\mathrm{O}(4)-\mathrm{V}(1)-\mathrm{O}(2)$ & $90.2(1)$ \\
\hline $\mathrm{O}(6)-\mathrm{V}(1)-\mathrm{N}(1)$ & $95.8(1)$ & $\mathrm{O}(1)-\mathrm{V}(1)-\mathrm{N}(1)$ & $83.3(1)$ \\
\hline $\mathrm{O}(4)-\mathrm{V}(1)-\mathrm{N}(1)$ & $162.5(1)$ & $\mathrm{O}(2)-\mathrm{V}(1)-\mathrm{N}(1)$ & $74.5(1)$ \\
\hline $\mathrm{O}(6)-\mathrm{V}(1)-\mathrm{O}(3)$ & $171.2(1)$ & $\mathrm{O}(1)-\mathrm{V}(1)-\mathrm{O}(3)$ & $81.4(1)$ \\
\hline $\mathrm{O}(4)-\mathrm{V}(1)-\mathrm{O}(3)$ & $76.0(1)$ & $\mathrm{O}(2)-\mathrm{V}(1)-\mathrm{O}(3)$ & $80.7(1)$ \\
\hline $\mathrm{N}(1)-\mathrm{V}(1)-\mathrm{O}(3)$ & $93.0(1)$ & & \\
\hline
\end{tabular}

Table 3. Hydrogen bond distances $(\AA)$ and bond angles $\left(^{\circ}\right)$ for the complexes

\begin{tabular}{lcccc}
\hline $\boldsymbol{D}-\mathrm{H} \cdots \boldsymbol{A}$ & $\boldsymbol{d}(\boldsymbol{D}-\mathbf{H}), \AA$ & $\boldsymbol{d}(\mathbf{H} \cdots \boldsymbol{A}), \AA$ & $\boldsymbol{d}(\boldsymbol{D} \cdots \boldsymbol{A}), \AA$ & Angle $(\boldsymbol{D}-\mathbf{H} \cdots \boldsymbol{A}), \mathbf{o}$ \\
\hline $\mathbf{1} \cdot \mathrm{MeOH}$ & & & \\
$\mathrm{O}(5)-\mathrm{H}(5) \cdots \mathrm{O}(6)^{\mathrm{i}}$ & $0.85(1)$ & $1.79(2)$ & $2.626(7)$ & $166(8)$ \\
$\mathrm{O}(6)-\mathrm{H}(6) \cdots \mathrm{N}(2)^{\mathrm{ii}}$ & 0.82 & 2.19 & $2.790(7)$ & 131 \\
$\mathbf{2} \cdot \mathrm{H}_{2} \mathrm{O}$ & & & & \\
$\mathrm{O}(5)-\mathrm{H}(5) \cdots \mathrm{O}(7)$ & 0.82 & 1.79 & $2.607(3)$ & 171 \\
$\mathrm{~N}(3)-\mathrm{H}(3) \cdots \mathrm{O}(5)$ & $0.90(1)$ & $1.99(3)$ & $2.608(3)$ & $125(3)$ \\
$\mathrm{N}(3)-\mathrm{H}(3) \cdots \mathrm{O}(4)^{\mathrm{iii}}$ & $0.90(1)$ & $2.59(3)$ & $3.310(3)$ & $138(3)$ \\
$\mathrm{O}(7)-\mathrm{H}(7 \mathrm{~A}) \cdots \mathrm{O}(1)^{\mathrm{iv}}$ & $0.85(1)$ & $2.04(2)$ & $2.853(3)$ & $160(4)$ \\
$\mathrm{O}(7)-\mathrm{H}(7 \mathrm{~A}) \cdots \mathrm{O}(3)^{\mathrm{iv}}$ & $0.85(1)$ & $2.61(3)$ & $3.225(3)$ & $131(3)$ \\
$\mathrm{O}(7)-\mathrm{H}(7 \mathrm{~B}) \cdots \mathrm{O}(6)^{\mathrm{iii}}$ & $0.85(1)$ & $2.23(3)$ & $2.808(3)$ & $125(3)$ \\
$\mathrm{O}(7)-\mathrm{H}(7 \mathrm{~B}) \cdots \mathrm{N}(2)^{\mathrm{v}}$ & $0.85(1)$ & $2.47(2)$ & $3.183(3)$ & $142(3)$ \\
\hline
\end{tabular}

Symmetry codes: i) $x,-1+y, z$; ii) $x, 1-y,-1 / 2+z$; iii) $1-x,-y, 1-z$; iv) $2-x,-y, 1-z$;

$$
\text { v) } x, y,-1+z \text {. }
$$

\section{Results and Discussion}

Replacement of two acetylacetonate ligands in $\left[\mathrm{VO}(\mathrm{acac})_{2}\right]$ by $\mathrm{H}_{2} \mathrm{~L}$ in methanol resulted in the formation of 1 (Scheme 2). The complex was further reacted with salicylhydroxamic acid to give complex 2 (Scheme 2). The latter complex can also be directly prepared by the reaction of $\mathrm{H}_{2} \mathrm{~L}$, salicylhydroxamic acid and $\left[\mathrm{VO}(\mathrm{acac})_{2}\right]$ in methanol. The $\mathrm{V}^{\mathrm{IV}}$ in $\left[\mathrm{VO}(\mathrm{acac})_{2}\right.$ ] was oxidized to $\mathrm{V}^{\mathrm{V}}$ by air during the reaction. Both complexes are soluble in
DMF, DMSO, methanol, ethanol, and acetonitrile, insoluble in water, chloroform and dichloromethane. Molar conductance of complexes $\mathbf{1}$ and $\mathbf{2}$ at the concentration of $10^{-4}$ $\mathrm{M}$ are 17 and $33 \Omega^{-1} \mathrm{~cm}^{2} \mathrm{~mol}^{-1}$, respectively, indicating they are non-electrolytes. ${ }^{12}$

\section{1. Crystal Structure Description of $1 \cdot \mathrm{MeOH}$}

The molecular structure and atom numbering scheme of complex $\mathbf{1}$ is shown in Figure 1. The V atom in the com- 
<smiles>C=Cc1cc(F)ccc1O</smiles>

1<smiles></smiles>

2

Scheme 2. The synthesis of the complexes

plex is in octahedral coordination, which is coordinated by one oxo oxygen, one neutral and one deprotonated methanol ligands, and the three donor atoms of the doubly deprotonated hydrazone ligand. The neutral methanol ligand is coordinated trans to the oxo oxygen, which is similar to those observed in the solvent coordinated vanadium complexes. ${ }^{3 a, 4}$ The vanadium to terminal oxo group $(\mathrm{O}(3))$ bond length for the complex (1.580(5) $\AA$ ) is within normal range for oxovanadium $(\mathrm{V})$ complexes. ${ }^{13}$ The short $\mathrm{V}(1)-\mathrm{O}(3)$ distance indicates the presence of a vanadiumoxygen double bond. ${ }^{14}$ The angular distortion in the octahedral environment around $\mathrm{V}$ comes from the five- and six-membered chelate rings taken by the hydrazone ligand, with angles of $83.6(2)^{\circ}$ and $74.2(2)^{\circ}$. Distortion of the octahedral coordination can be observed from the coordinate bond angles, ranging from $74.2(2)$ to $103.2(2)^{\circ}$ for the perpendicular angles, and from 153.1(2) to $175.5(2)^{\circ}$ for the diagonal angles. Relative to the equatorial plane defined by $\mathrm{O}(1), \mathrm{O}(2), \mathrm{O}(4)$ and $\mathrm{N}(1)$, the vanadium atom is displaced toward the axial oxygen atom O3 by $0.291(1) \AA$. The dihedral angle between the two benzene rings is $83.6(3)^{\circ}$. The double deprotonated form of the hydrazone ligand is consistent with the observed $\mathrm{O} 2-\mathrm{C} 8$ and $\mathrm{N} 2-\mathrm{C} 8$ bond lengths of 1.292(7) $\AA$ and 1.302(7) $\AA$, respectively. This is in agreement with reported vanadium complexes containing the enolate form of hydrazone ligands. ${ }^{4,13 b}$

In the crystal of $\mathbf{1}$, the vanadium complexes are linked by methanol molecules through intermolecular $\mathrm{O}(5)-\mathrm{H}(5) \cdots \mathrm{O}(6)$ and $\mathrm{O}(6)-\mathrm{H}(6) \cdots \mathrm{N}(2)$ hydrogen bonds, to form chains along the $c$ axis (Figure 2).

\section{2. Crystal Structure Description of $2 \cdot \mathrm{H}_{2} \mathrm{O}$}

The molecular structure and atom numbering scheme of complex $\mathbf{2}$ is shown in Figure 3. The V atom in the com- plex is in octahedral coordination, which is coordinated by one oxo oxygen, one hydroxyl and one carbonyl oxygen atoms of SHA ligand, and the three donor atoms of the hydrazone ligand. The carbonyl oxygen atom is coordinated trans to the oxo oxygen, with the bond length much longer than the remaining ones. The vanadium to terminal oxo group $(\mathrm{O}(6))$ bond length for the complex $(1.577(2) \AA)$ is comparable to that in complex $\mathbf{1}$, and within normal range for oxovanadium $(\mathrm{V})$ complexes. ${ }^{13}$ The short $\mathrm{V}(1)-\mathrm{O}(6)$ distance indicates the presence of a vanadium-oxygen double bond..$^{14}$ The coordinate bond lengths in the complex are comparable to those observed in $\mathbf{1}$ and the oxovanadium(V) complexes with octahedral coordination. ${ }^{4}$ The angular distortion in the octahedral environment around V comes from the five- and six-membered chelate rings taken by the hydrazone ligand, with angles of $83.34(9)^{\circ}$ and $74.47(8)^{\circ}$. Distortion of the octahedral coordination can be observed from the coordinate bond angles, ranging from $74.5(1)$ to $107.8(1)^{\circ}$ for the perpendicular angles, and from $150.6(1)$ to $171.2(1)^{\circ}$ for the diagonal angles. Relative to the equatorial plane defined by $\mathrm{O}(1), \mathrm{O}(2), \mathrm{O}(4)$ and $\mathrm{N}(1)$, the vanadium atom is displaced toward the axial oxygen atom O3 by $0.268(1) \AA$. The dihedral angle between the substituted benzene rings is $21.0(3)^{\circ}$. The double deprotonated form of the hydrazone ligand is consistent with the observed O2-C8 and N2-C8 bond lengths of 1.302(3) $\AA$ and 1.297(3) $\AA$, respectively. This is in agreement with reported vanadium complexes containing the enolate form of hydrazone ligands. ${ }^{4,13 b}$

In the crystal of 2 , the vanadium complexes are linked by water molecules through intermolecular $\mathrm{O}(7)$ $\mathrm{H}(7 \mathrm{~B}) \cdots \mathrm{O}(6)$ and $\mathrm{O}(7)-\mathrm{H}(7 \mathrm{~A}) \cdots \mathrm{O}(1)$ hydrogen bonds, to form $1 \mathrm{D}$ chains along the $a$ axis. The chains are further linked through intermolecular $\mathrm{O}(5)-\mathrm{H}(5) \cdots \mathrm{O}(7)$ and $\mathrm{O}(7)-\mathrm{H}(7 \mathrm{~A}) \cdots \mathrm{O}(3)$ hydrogen bonds in the $c$ direction, to form 2D layers (Figure 4). 

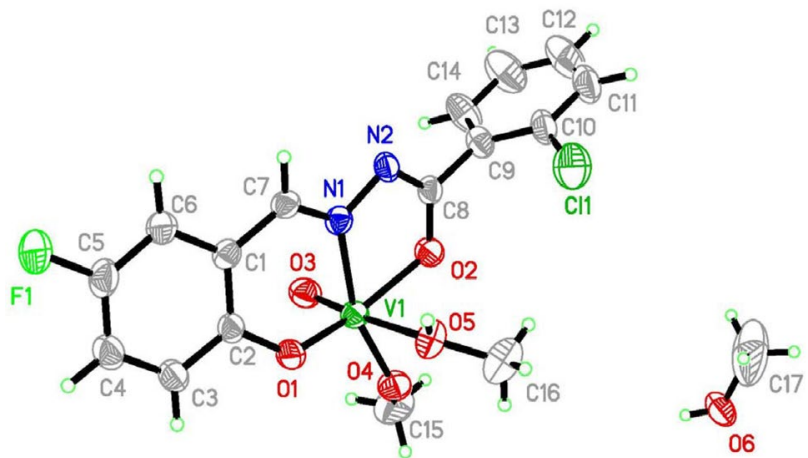

Figure 1. ORTEP plot of the crystal structure of $\mathbf{1}$. Displacement ellipsoids of non-hydrogen atoms are drawn at the $30 \%$ probability level.

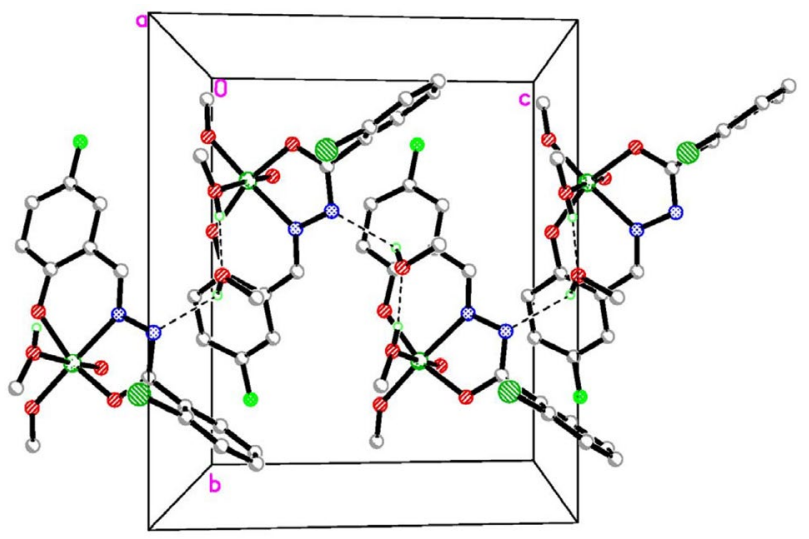

Figure 2. Molecular packing diagram of $\mathbf{1}$. Viewed along the $a$ axis. Hydrogen atoms not related to hydrogen bonding are omitted. Hydrogen bonds are shown as dashed lines.

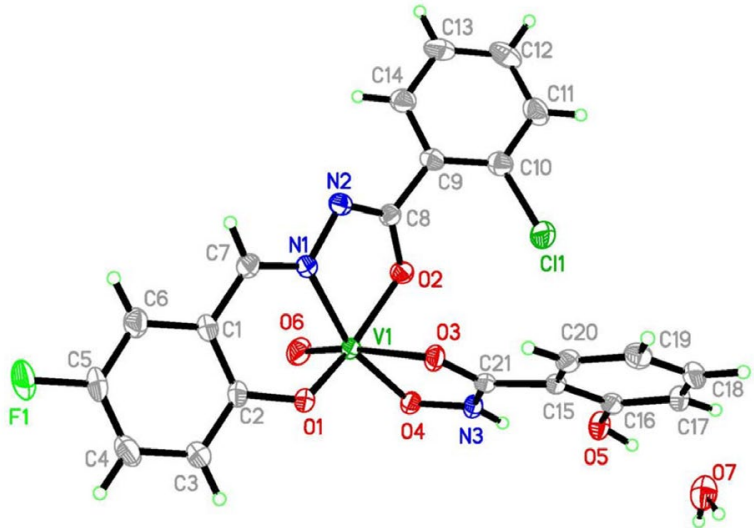

Figure 3. ORTEP plot of the crystal structure of 2. Displacement ellipsoids of non-hydrogen atoms are drawn at the $30 \%$ probability level.

\section{3. IR and Electronic Spectra}

The hydrazone ligand showed stretching bands attributed to $\mathrm{C}=\mathrm{O}, \mathrm{C}=\mathrm{N}, \mathrm{C}-\mathrm{OH}$ and $\mathrm{NH}$ at about 1651 , 1619,1155 and 1220 , and $3232 \mathrm{~cm}^{-1}$, respectively. The complexes exhibit typical bands at about $980 \mathrm{~cm}^{-1}$, as-

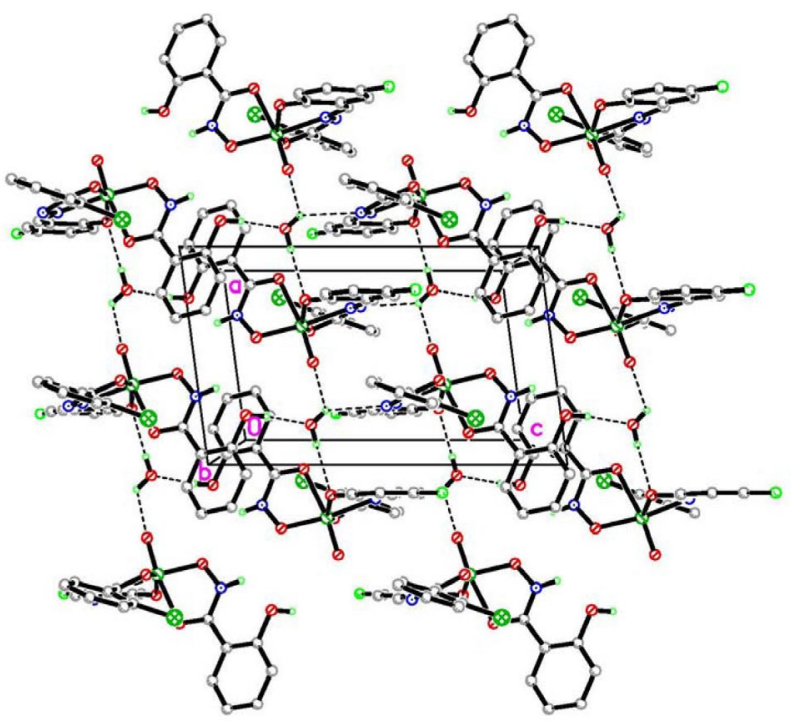

Figure 4. Molecular packing diagram of 2. Viewed along the $c$ axis. Hydrogen atoms not related to hydrogen bonding are omitted. Hydrogen bonds are shown as dashed lines.

signed to the $\mathrm{V}=\mathrm{O}$ vibration. ${ }^{15}$ In the spectrum of $\mathbf{1}$, the bands due to $v_{\mathrm{C}=\mathrm{O}}$ and $v_{\mathrm{NH}}$ were absent, but new $\mathrm{C}-\mathrm{O}$ stretch appeared at $1253 \mathrm{~cm}^{-1}$. This suggests occurrence of keto-imine tautomerization of the hydrazone ligand during complexation. The same phenomenon should occur in complex 2. But the existence of $v_{\mathrm{NH}}$ at $3278 \mathrm{~cm}^{-1}$ made an interruption. The $v_{\mathrm{C}=\mathrm{N}}$ absorption observed at $1619 \mathrm{~cm}^{-1}$ in the free hydrazone ligand shifted to $1607 \mathrm{~cm}^{-1}$ for both complexes upon coordination to the $\mathrm{V}$ atoms. ${ }^{16}$ The weak peaks in the low wave numbers in the region 400-650 $\mathrm{cm}^{-1}$ may be attributed to $\mathrm{V}-\mathrm{O}$ and $\mathrm{V}-\mathrm{N}$ bonds in the complexes.

Methanol solutions of the complexes are brown-yellow in color. These solutions have been used to record the electronic spectra. The hydrazone ligands and their vanadium $(\mathrm{V})$ complexes have bands in the range 205-240 and 300-330 nm, which can be assigned as $\pi \rightarrow \pi^{*}$ and $n \rightarrow \pi^{*}$ transitions, respectively. All bands shift to lower energy in complexes indicating the coordination of ligands to the vanadium ions. The shoulder at about $270 \mathrm{~nm}$ for the complexes corresponds to LMCT band of $\mathrm{V}=\mathrm{O}$ which it is observed at $274 \mathrm{~nm}$ for $\left[\mathrm{VO}(\mathrm{acac})_{2}\right]^{14}$

\section{4. Thermal Property}

Differential thermal and thermal gravimetric analyses were conducted to examine the stability of the complexes. For 1 (Figure 5), the first step started at $50{ }^{\circ} \mathrm{C}$ and ended at $160{ }^{\circ} \mathrm{C}$, with a weight loss of $14.0 \%$, might be caused by the loss of the lattice and coordinated neutral methanol molecules. Then the complex continued to decompose, until $470{ }^{\circ} \mathrm{C}$, corresponding to the loss of the remaining parts of the ligands, and formation of $\mathrm{V}_{2} \mathrm{O}_{5}$. The total weight loss of $78.5 \%$ is in agreement with the ideal 
value of $79.9 \%$. For 2 (Figure 6), this complex is not very stable in air at room temperature. It might have lost the lattice water molecules before the thermal analysis. The complex started to decompose at $109^{\circ} \mathrm{C}$ and completed at $470{ }^{\circ} \mathrm{C}$, corresponding to the loss of the hydrazone and salicylhdroxamate ligands, and formation of $\mathrm{V}_{2} \mathrm{O}_{5}$. The total weight loss of $83.7 \%$ is in agreement with the ideal value of $85.5 \%$.

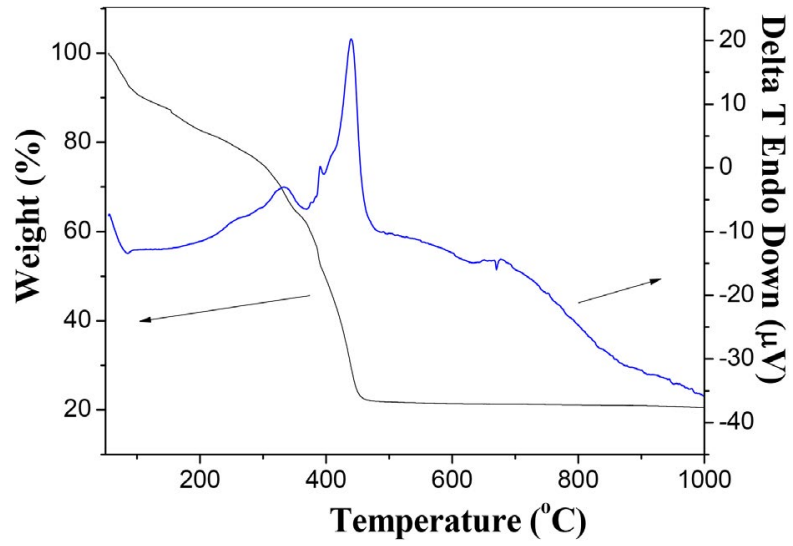

Figure 5. DT-TGA curves of 1.

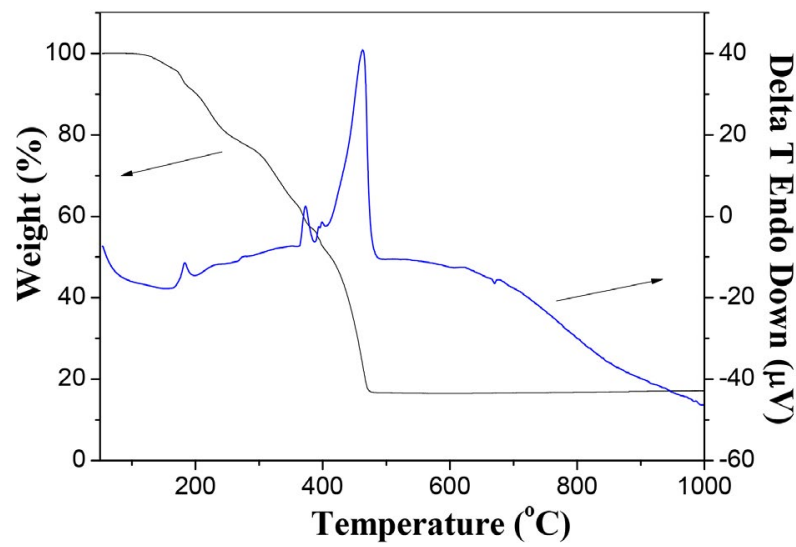

Figure 6. DT-TGA curves of 2.

\section{5. Antibacterial Activity}

The free benzohydrazone and the vanadium complexes were assayed for in vitro antibacterial activity against $K$. pneumoniae, S. aureus, P. aeroginosa, E. coli, and B. subtilis at $50 \mu \mathrm{g} \mathrm{mL}^{-1}$ using ethanol as solvent and control, and using tetracyclin as the standard drug. The minimum inhibitory concentrations (MIC) were determined by broth micro-dilution method. ${ }^{17}$ The observed MIC values in $\mu \mathrm{g} \mathrm{mL}^{-1}$ are reported in Table 4 . The antibacterial activity was evaluated by measuring the zone of inhibition in $\mathrm{mm}$. Ethanol had no antibacterial activity on the bacteria at the concentration studied. The results revealed that the hydrazone compound and the two complexes showed from weak to effective activities against the tested microorganisms. In general, the complexes showed higher activities than the free aroylhydrazones. Such an enhancement in the activity of metal complexes against certain specific microorganisms may be explained on the basis of Overtone's concept and Tweedy's chelation theory. ${ }^{18}$ The least MIC with $11 \mu \mathrm{g} \mathrm{mL}^{-1}$ was observed for complex 1 against $S$. aureus. The activity on B. subtilis and S. aureus of the free hydrazone is less than $N^{\prime}$-(5-chloro-2-hydroxybenzylidene)-4-hydroxybenzohydrazide $\left(\mathrm{H}_{2} \mathrm{~L}\right)$, but on E. coli, the free hydrazone is higher than the above mentioned compound. ${ }^{19}$ The activity of the complexes on S. aureus and $E$. coli is similar to the vanadium complex with L' and 2-hydroxybenzoate ligands, while on B. subtilis, the complexes are much less than the vanadium complex mentioned above. ${ }^{19}$ Thus, more work need to be done to find the relationship between the structures and the antibacterial activities.

\section{Supplementary Material}

CCDC-978393 for $\mathbf{1}$ and 978394 for $\mathbf{2}$ contain the supplementary crystallographic data for this paper. These data can be obtained free of charge at http://www.ccdc. cam.ac.uk/const/retrieving.html or from the Cambridge Crystallographic Data Centre (CCDC), 12 Union Road, Cambridge CB2 1EZ, UK; fax: $+44(0) 1223-336033$ or e-mail: deposit@ccdc.cam.ac.uk.

\section{References}

1. (a) G. R. Willsky, A. B. Goldfine, P. J. Kostyniak, J. H. McNeill, L. Q. Yang, H. R. Khan, D. C. Crans, J. Inorg. Biochem. 2001, 85, 33-42; DOI:10.1016/S0162-0134(00)00226-9

(b) P. Caravan, L. Gelmini, N. Glover, F. G. Herring, H. L. Li, J. H. McNeill, S. J. Rettig, I. A. Setyawati, E. Shuter, Y. Sun, A. S. Tracey, V. G. Yuen, C. Orvig, J. Am. Chem. Soc. 1995, 117, 12759-12770; DOI:10.1021/ja00156a013

(c) A. Messerschmidt, L. Prade, R. Wever, Biol. Chem. 1997, 378, 309-315. DOI:10.1515/bchm.1997.378.3-4.309

Table 4. Minimum inhibitory concentrations (MICs, $\mu \mathrm{g} \mathrm{mL}^{-1}$ ) of the compounds

\begin{tabular}{lccccc}
\hline Compound & K. pneumoniae & S. aureus & P. aeroginosa & E. coli & B. subtilis \\
\hline $\mathrm{H}_{2} \mathrm{~L}$ & 27 & 35 & $>50$ & 22 & 36 \\
$\mathbf{1}$ & 15 & 11 & $>50$ & 17 & 23 \\
$\mathbf{2}$ & 17 & 13 & $>50$ & 14 & 19 \\
\hline
\end{tabular}

Liu et al.: Synthesis, Spectroscopic Characterization, Crystal ... 
2. (a) M. D. Altintop, A. Ozdemir, G. Turan-Zitouni, S. Ilgin, O. Atli, G. Iscan, Z. A. Kaplancikli, Eur. J. Med. Chem. 2012, 58, 299-307; DOI:10.1016/j.ejmech.2012.10.011

(b) X.-L. Wang, Z.-L. You, C. Wang, J. Chem. Crystallogr. 2011, 41, 621-624; DOI:10.1016/j.bmc.2011.04.027

(c) M. A. A. El-Sayed, N. I. Abdel-Aziz, A. A. M. Abdel-Aziz, A. S. El-Azab, Y. A. Asiri, K. E. H. El Tahir, Bioorg. Med. Chem. 2011, 19, 3416-3424.

3. (a) L. L. Wang, W. Li, Y. J. Mei, Russ. J. Coord. Chem. 2019, 45, 154-162; DOI:10.1134/S1070328419020118

(b) Z.-L. You, D.-H. Shi, J.-C. Zhang, Y.-P. Ma, C. Wang, K. Li, Inorg. Chim. Acta 2012, 384, 54-61;

DOI:10.1016/j.ica.2011.11.039

(c) S. Y. Li, W. Q. Zhai, Z. W. Li, A. Li, Y. M. Jiang, W. Li, Russ. J. Coord. Chem. 2018, 44, 701-706; DOI:10.1134/S1070328418110052

(d) Z.-L. You, Y.-M. Cui, Y.-P. Ma, C. Wang, X.-S. Zhou, K. Li, Inorg. Chem. Commun. 2011, 14, 636-640.

DOI:10.1016/j.inoche.2011.01.038

4. (a) N. A. Lalami, H. H. Monfared, H. Noei, P. Mayer, Transition Met. Chem. 2011, 36, 669-677;

DOI:10.1007/s11243-011-9517-8

(b) T. N. Mandal, S. Roy, A. K. Barik, S. Gupta, R. J. Butcher,

S. K. Kar, Polyhedron 2008, 27, 3267-3274.

DOI:10.1016/j.poly.2008.07.024

5. S. Gao, Z.-Q. Weng, S.-X. Liu, Polyhedron 1998, 17, 35953606. DOI:10.1016/S0277-5387(98)00154-5

6. S. P. Rath, K. K. Rajak, S. Mondal, A. Chakravorty, J. Chem. Soc. Dalton Trans. 1998, 2097-2101. DOI:10.1039/a801355a

7. M. Sutradhar, T. R. Barman, G. Mukherjee, M. G. B. Drew, S. Ghosh, Polyhedron 2012, 34, 92-101.

DOI:10.1016/j.poly.2011.12.022

8. M. Zhang, D.-M. Xian, H.-H. Li, J.-C. Zhang, Z.-L. You, Aust. J. Chem. 2012, 65, 343-350. DOI:10.1071/CH11424
9. Bruker, SMART and SAINT, Bruker AXS Inc., Madison, Wiscon sin, USA, 2012.

10. G. M. Sheldrick, SADABS Program for Empirical Absorption Correction of Area Detector, University of Göttingen, Germany, 1996.

11. G. M. Sheldrick, Acta Crystallogr. 2008, A64, 112-122. DOI:10.1107/S0108767307043930

12. W. J. Geary, Coord. Chem. Rev. 1971, 7, 81-122. DOI:10.1016/S0010-8545(00)80009-0

13. (a) M. R. Prathapachandra Kurup, E. B. Seena, M. Kuriakose, Struct. Chem. 2010, 21, 599-605; DOI:10.1007/s11224-010-9589-7

(b) Y. Li, L. Xu, M. Duan, J. Wu, Y. Wang, K. Dong, M. Han, Z. You, Inorg. Chem. Commun. 2019, 105, 212-216. DOI:10.1016/j.inoche.2019.05.011

14. H. H. Monfared, R. Bikas, P. Mayer, Inorg. Chim. Acta 2010, 363, 2574-2583. DOI:10.1016/j.ica.2010.04.046

15. S. Guo, N. Sun, Y. Ding, A. Li, Y. Jiang, W. Zhai, Z. Li, D. Qu, Z. You, Z. Anorg. Allg. Chem. 2018, 644, 1172-1176. DOI:10.1002/zaac.201800060

16. H. Yu, S. Guo, J.-Y. Cheng, G. Jiang, Z. Li, W. Zhai, A. Li, Y. Jiang, Z. You, J. Coord Chem. 2018, 71, 4164-4179.

DOI:10.1080/00958972.2018.1533959

17. J. H. Jorgensen, J. D. Turnidge, Manual of Clinical Microbiology, Washington (DC, USA): American Society for Microbiology, 2003.

18. (a) N. Dharamaraj, P. Viswanathamurthi, K. Natarajan, Transition Met. Chem., 2001, 26, 105-109;

DOI:10.1023/A:1007132408648

(b) J. W. Searl, R. C. Smith, S. Wyard, J. Proc. Phys. Soc., 1961, 78, 1174-1181. DOI:10.1088/0370-1328/78/6/311

19. C. Li, Y.-L. Dong, X.-F. Meng, X. Zhou, J.-J. Ma, Synth. React. Inorg. Met.-Org. Nano-Met. Chem., 2016, 46, 118-122. DOI:10.1080/15533174.2014.900791

\section{Povzetek}

Nov vanadijev(V) kompleks, [VOL $(\mathrm{OMe})(\mathrm{MeOH})] \cdot \mathrm{MeOH}(\mathbf{1} \cdot \mathrm{MeOH})$, smo pripravili z reakcijo $\mathrm{VO}(\operatorname{acac})_{2} \mathrm{z}$ 2-kloro- $N$ '-(5-fluoro-2-hidroksibenziliden)benzohidrazidom $\left(\mathrm{H}_{2} \mathrm{~L}\right)$ v metanolu. $\mathrm{Z}$ dodatkom salicilhidroksamske kisline (HSHA) k metanolni raztopini 1, smo izolirali nov salicilhidroksamato vanadijev(V) kompleks, $[\mathrm{VOL}(\mathrm{SHA})] \cdot \mathrm{H}_{2} \mathrm{O}$ $\left(2 \cdot \mathrm{H}_{2} \mathrm{O}\right)$. Oba kompleksa smo okarakterizirali z elementno analizo, infrardečo spektroskopijo, termično analizo in rentgensko monokristalno analizo. Kompleks 1 kristalizira z molekulo metanola kot solvatom in kompleks 2 kot hidrat. $\mathrm{V}$ kompleksih so $\mathrm{V}$ atomi oktaedrično koordinirani. $\mathrm{V}$ kristalni strukturi $\mathbf{1} \cdot \mathrm{MeOH}$ so vanadijevi kompleksi povezani $\mathrm{z}$ molekulo metanola preko intramolekularnih $\mathrm{O}-\mathrm{H} \cdots \mathrm{N}$ in $\mathrm{O}-\mathrm{H} \cdots \mathrm{O}$ vodikovih vezi v verige vzdolž osi $c$. V kristalni strukturi $2 \cdot \mathrm{H}_{2} \mathrm{O}$ so vanadijevi kompleksi povezani $\mathrm{z}$ molekulo vode preko intermolekularnih $\mathrm{O}-\mathrm{H} \cdots \mathrm{O}$ vodikovih vezi v verige vzdolž osi $a$. Nadalje so verige povezane v plasti preko intermolekularnih intermolekularnih $\mathrm{O}-\mathrm{H} \cdots \mathrm{N}$ in $\mathrm{O}-\mathrm{H} \cdots \mathrm{O}$ vodikovih vezi vzdolž osi $c$. Določili smo tudi antimikrobno aktivnost obeh kompleksov proti K. pneumoniae, S. aureus, P. aeroginosa, E. coli in B. subtilis.

Except when otherwise noted, articles in this journal are published under the terms and conditions of the Creative Commons Attribution 4.0 International License 